\title{
Reducing Wooden Structure and Wildland-Urban Interface Fire Disaster Risk through Dynamic Risk Assessment and Management
}

\author{
Torgrim Log ${ }^{1}\left(\mathbb{D}\right.$, Vigdis Vandvik $^{2}$, Liv Guri Velle ${ }^{3 \oplus \mathbb{D}}$ and Maria-Monika Metallinou ${ }^{1, *}$ \\ 1 Fire disaster research group, Western Norway University of Applied Sciences, 5528 Haugesund, Norway; \\ torgrim.log@hvl.no \\ 2 Department of Biological Sciences and Bjerknes Centre for Climate Research, University of Bergen, \\ 5020 Bergen, Norway; vigdis.vandvik@uib.no \\ 3 Møreforsking Ålesund, 6009 Ålesund, Norway; liv.guri.velle@moreforsk.no \\ * Correspondence: monika.metallinou@hvl.no; Tel.: +47-9885-5104
}

Received: 22 February 2020; Accepted: 16 March 2020; Published: 18 March 2020

\begin{abstract}
In recent years, severe and deadly wildland-urban interface (WUI) fires have resulted in an increased focus on this particular risk to humans and property, especially in Canada, USA, Australia, and countries in the Mediterranean area. Also, in areas not previously accustomed to wildfires, such as boreal areas in Sweden, Norway, and in the Arctic, WUI fires have recently resulted in increasing concern. January 2014, the most severe wooden town fire in Norway since 1923 raged through Lærdalsøyri. Ten days later, a wildfire raged through the scattered populated community of Flatanger and destroyed even more structures. These fires came as a surprise to the fire brigades and the public. We describe and analyze a proposed way forward for exploring if and how this increasing fire incidence can be linked to concomitant changes in climate, land-use, and habitat management; and then aim at developing new dynamic adaptive fire risk assessment and management tools. We use coastal Norway as an example and focus on temporal changes in fire risk in wooden structure settlements and in the Norwegian Calluna vulgaris L. dominated WUI. In this interface, the fire risk is now increasing due to a combination of land-use changes, resulting in large areas of early successional vegetation with an accumulation of biomass, and the interactive effects of climatic changes resulting in increased drought risk. We propose a novel bow-tie framework to explore fire risk and preventive measures at various timescales (years, months, weeks, hours) as a conceptual model for exploring risk contributing factors and possibilities for risk management. Ignition is the top event of the bow-tie which has the potential development towards a fire disaster as a worst case outcome. The bow-tie framework includes factors such as changes in the built environment and natural habitat fuel moisture content due to the weather conditions, WUI fuel accumulation, possibly improved ecosystem management, contribution by civic prescribed burner groups, relevant fire risk modeling, and risk communication to the fire brigades and the public. We propose an interdisciplinary research agenda for developing this framework and improving the current risk understanding, risk communication, and risk management. This research agenda will represent important contributions in paving the road for fire disaster prevention in Norway, and may provide a model for other systems and regions.
\end{abstract}

Keywords: wooden structure conflagrations; wildland-urban interface (WUI); fire risk; Calluna vulgaris; weather conditions; temporal and spatial changes; prescribed burning; fire risk management; risk communication 


\section{Introduction}

Although nowadays seen mainly as a threat, fire has for millennia been a highly valued tool and an integral part of human societies. Fires were first used for deforestation to get access to good hunting hollows [1]. Later on, agricultural activities and permanent housings developed. Gradually, towns were established, and where easily available, timber was increasingly introduced as the main construction material. Succeeding the development of wooden towns, one of the most severe peace time threats to lives and property was potential fire disasters that could completely ruin the wooden structure settlements. Norway was no exception and major fires represented a challenge to nearly all the towns during the centuries [2]. On several occasions, the city of Bergen was on the brink of complete destruction. During the 20th century, fewer conflagrations were fortunately observed. This fire risk is, nevertheless, not always controlled and the list of major conflagrations still grows.

Four months after a devastating fire in Ålesund on 23rd January 1904, destroying 850 structures and resulting in 10,000-12,000 homeless people, the Norwegian Parliament introduced a new law requiring all new town structures to be composed of noncombustible materials. Villages and small towns were, however, exempt from this law. Due to the abundant forests covering the Norwegian lowlands in the south and the coastal areas all the way north to the Polar Circle, resulting in inexpensive wooden construction materials, close to $100 \%$ of the homes in villages in rural areas were constructed of wooden materials. This is also the case in the 21st century. The fire threat to these constructions may be a result of internal or external ignition. External ignition sources may be a result of glowing embers from other structures or wildland fuel involved in fires.

Fires are usually, but not always, associated with warm and dry weather. Pirsko and Fons [3] suggested ambient air dew point as an explanation for high frequency of building fires in the cold season. Perhaps counterintuitively, conflagrations in Norway were also more common during the winter season [2]. As an example, the January 18-19th 2014 subzero temperature fire in Lærdalsøyri destroyed 40 structures and threatened the whole town. This fire clearly showed that conflagrations are still a threat $[4,5]$. The severity of that fire was a result of (a) drying of outdoor wood-based materials, (b) extremely low indoor relative humidity $(\mathrm{RH})$ resulting in very dry indoor wood materials and very fast fire development [6], and (c) strong winds spreading the fire long distances. Five days later, 32 seniors died in an extremely fast developing subzero temperature wooden structure fire in Quebec, Canada [7]. A recent study [8] revealed that indoor $\mathrm{RH}$ can be used as a fire risk indicator. A 2-5 day time lag in indoor RH was observed after a step change to cold weather, i.e., corresponding to the drying of the internal wooden wall materials. A similar time lag in fire frequency versus ambient low temperatures was also recently found for cold climate urban fire frequency in China [9].

Wildland urban interface (WUI) fires are an increasing risk, particularly in the USA, Canada, Australia and the Mediterranean area. This is a result of accumulated vegetation biomass in combination with dry and warm climates often resulting in much accumulated dead biomass with very low fuel moisture content. In 2009, the Black Saturday bushfires in Australia killed 168 people [10]. In the European Union (EU), the yearly average area burned by wildfires has declined significantly since 1980. However, when wildfires in the EU occur, the fires now cause significantly more destruction than in previous years [11]. The June 2017 Portugal wildfires killed 66 people. The Iberian fires four months later killed 45 people in Portugal and four people in Spain. In July 2018, the Attica fires, Greece, killed 102 people and destroyed 1000 homes. Three months later, the $629 \mathrm{~km}^{2}$ (62,900 ha) Camp Fire, California, killed 88 people and destroyed 18,800 homes [12]. Fighting huge WUI fires is also very dangerous, as illustrated by the nineteen firefighters killed in the 2013 Yarnell Hill wildfire, AZ, USA [13].

Boomtowns in remote areas, and without proper risk assessment and risk mitigation, have resulted in major conflagrations. The $3000 \mathrm{~km}^{2}$ (300,000 ha) Fort McMurray fire, Canada, led to evacuation of 88,000 residents and the destruction of 2400 homes [14]. Smaller WUI fires, without loss of lives or structures, may also result in loss of commercial activity in the exposed local societies [15]. 
In 2018, the weather conditions in Norway and Sweden, from April to July, were extremely dry and warm, and with a minimum of precipitation. This resulted in severe wildfires burning $250 \mathrm{~km}^{2}$ (25,000 ha) in Sweden. In Norway, 2110 vegetation fires occurred in this period and one firefighter lost his life fighting one of these wildfires [16]. The 2018 fires in Norway were, however, due to the low wind strengths small and generally controlled by the firefighters. In April 2019, a $7 \mathrm{~km}^{2}$ (700 ha) wildfire in South-West Norway (Sokndal and Lyngdal) resulted in evacuation of 250 inhabitants and hikers being rescued by helicopter minutes before being over-run by fire. It is quite clear that a better focus on risk management, urban settlement planning, and wildland management is needed also in Scandinavia. Developing a game-changing interdisciplinary approach was suggested by Uhr et al. [17] in the aftermath of the $150 \mathrm{~km}^{2}$ (15,000 ha) Västmansland wildfire in 2014, i.e., the largest wildfire in Sweden in the last 50 years.

Succeeding the extreme 1985 fire season, the National Fire Protection Association (NFPA) and the USDA Forest Service started discussing initiatives and measures regarding the increasing trend of wind-driven fire in populated areas. The advisory group formed what is currently named the National Wildland/Urban Interface Fire Program. In 1992, the term FireWise was coined and in 1999, the advisory group was named the WUI Working Team. At about the same time, the similar FireSmart program was initiated in Canada. The experiences from these programs, e.g., [18-22], and similar programs elsewhere, may turn out to be very valuable also in a Scandinavian setting. Given the expected future climate changes, engaging the public in programs similar to FireWise and FireSmart may be a necessity.

During the last decades, especially researchers in the USA and the Mediterranean countries have focused very much on fire spread from the wildland to buildings, e.g., [23-26]. Manzello and Foote [23] characterized firebrand exposure from WUI fires. A recent American Planning Association publication by Mowery et al. [24] summarized US WUI fire research and presented measures to reduce the WUI fire risk based on lessons learned from major WUI fires and fire testing. Key concepts and evaluation methodologies were presented by Bento-Gonçalves and Vieira [25] in a study where they also reviewed research published in French, Spanish, and Portuguese languages. They identified a major increase in the number of WUI fire studies during the last two decades and addressed the need for standardized methodologies to facilitate knowledge transfer and promote interdisciplinary cooperation. Badia et al. [26] analyzed wildfires and the WUI interface land use and land cover change in Catalonia, Spain from 1956 to 2010. They presented territorial typology changes during these decades, changes that have taken different forms, but all shared a common trait, i.e., that abandonment of traditional activities affected the WUI fire vulnerability negatively.

Research in Japan and the USA has also focused on fire spread between wooden structures, e.g., $[27,28]$. Due to increased international challenges regarding large outdoor fires and the built environment, the International Association of Fire Safety Sciences (IAFSS) established an international work group on this issue after discussions at the IAFSS 2017 conference in Lund, Sweden [29]. The work group objectives and goals were presented by Manzello et al. [30]. Such initiatives clearly show that the fire disaster risk needs to be better managed.

It should also be mentioned that, when it comes to vulnerability, natural disasters caused by, e.g., earthquakes, flooding, extreme heat waves, drought, forest fires, and coastal erosion, show many similarities when it comes to the societal vulnerability impacts. This was highlighted in the European Commission project named "Methods for the Improvement of Vulnerability Assessment in Europe (MOVE)" [31]. Most risk parameters they defined were hazard independent, and could therefore also be used in a multi-hazard vulnerability assessment. Capacities in anticipation, coping and recovering were analyzed. Working with stakeholders was a positive experience since most of them recognized the importance of assessing vulnerability, and were open to consider it in their daily risk management activities.

To reduce the fire disaster risk requires an interdisciplinary and multi-faceted approach, which may be summarized in five "P"s suggested by Keeley and Syphard [12]. People come into the picture both as 
an ignition source (directly via, e.g., cigarettes or indirectly via, e.g., power lines) and as potential victims of an ignited fire. The problem is partly solved if human ignition is prevented, especially in windy and dry conditions. However, lightening is also a major ignition source especially in wildfires. Planning may have been done without considering potential extreme fire events. Especially when planning has failed, the protection of homes from fires is critical. The fifth " $\mathrm{P}$ " is the prediction of extreme wind conditions in real time and communicating such information to fire briga $\overline{d e s}$, homeowners and the public.

The high fire disaster frequency experienced in the recent years and the climate changes expected during the next decades represent alarming signals for the future. There is therefore an urgent need for innovative and interdisciplinary research to (a) understand the complexity and (b) to proactively manage the increasing fire disaster risk. This implies increased capacity in dynamic risk anticipation. The motivation for the present paper is to communicate an innovative and interdisciplinary research agenda to approach to these challenges. The present paper briefly outlines fire as a threat in Section 2, with emphasis on dry fuel fire dynamics. Parameters influencing the fire disaster risk in different time scales and possibilities for mitigating these are presented in Section 3. A research agenda framework is presented in Section 4 and the suggested approach is discussed in Section 5, where comments are made on the likelihood of success of such an approach.

\section{Fire as a Threat}

\subsection{Fire Dynamics}

In fires, the most important parameter characterizing the fire behavior is the heat release rate (HRR) [32]:

$$
\dot{Q}_{\mathrm{c}}=A_{\mathrm{f}} \cdot \dot{m}_{\mathrm{f}}^{\prime \prime} \cdot \chi \cdot \Delta H_{\mathrm{c}}(\mathrm{W})
$$

where $A_{f}\left(\mathrm{~m}^{2}\right)$ is the fuel surface area, $\dot{m}_{f}^{\prime \prime}\left(\mathrm{kg} / \mathrm{m}^{2} \mathrm{~s}\right)$ is the fuel surface mass flux, $\chi$ is the burning efficiency $(\leq 1)$ and $\Delta H_{c}(\mathrm{~J} / \mathrm{kg})$ is the heat of combustion for the fuel involved. With the exception of solid phase oxidation of char coal, the combustion takes place in the gas phase (flame) where the products released from the fuel surface react with oxygen entrained in the flame zone.

The incoming heat flux to the surface of the fuel consists of the heat flux from engulfing flames and hot gases, $\dot{Q}_{\mathrm{F}}^{\prime \prime}\left(\mathrm{W} / \mathrm{m}^{2}\right)$, and any radiant heat flux from external heat sources, $\dot{Q}_{\mathrm{E}}^{\prime \prime}\left(\mathrm{W} / \mathrm{m}^{2}\right)$. The incoming heat flux is balanced by the inwards and outwards surface heat losses, $\dot{Q}_{\mathrm{L}}^{\prime \prime}\left(\mathrm{W} / \mathrm{m}^{2}\right)$, and the enthalpy required for pyrolyzing the fuel, $L_{\mathrm{V}}(\mathrm{J} / \mathrm{kg})$, at the respective fuel surface mass flux, $\dot{m}_{\mathrm{f}}$ :

$$
\dot{Q}_{\mathrm{F}}^{\prime \prime}+\dot{Q}_{\mathrm{E}}^{\prime \prime}=\dot{Q}_{\mathrm{L}}^{\prime \prime}+\dot{m}_{\mathrm{f}}^{\prime \prime} \cdot L_{\mathrm{V}}\left(\mathrm{W} / \mathrm{m}^{2}\right)
$$

Solving Equation (2) for the mass flux gives:

$$
\dot{m}_{\mathrm{f}}^{\prime \prime}=\frac{\dot{Q}_{\mathrm{F}}^{\prime \prime}+\dot{Q}_{\mathrm{E}}^{\prime \prime}-\dot{Q}_{\mathrm{L}}^{\prime \prime}}{L_{\mathrm{V}}}\left(\mathrm{kg} / \mathrm{m}^{2} \mathrm{~s}\right)
$$

Fire spread is generally caused by direct flame contact (convection), heat radiation, and by airborne firebrands and glowing embers. Virgin fuel needs to be heated to temperatures well above $100{ }^{\circ} \mathrm{C}$ to be involved in the combustion. The term $L_{\mathrm{V}}$ therefore includes heating the fuel to $100{ }^{\circ} \mathrm{C}$, drying it at about $100{ }^{\circ} \mathrm{C}$, heating it to temperatures typical for the onset of pyrolysis, pyrolysing it, and further heating the pyrolysis products to the ignition temperature.

Since the heat of vaporization for water is very high $\left(\Delta H_{\mathrm{vap}}=2.444 \mathrm{MJ} / \mathrm{kg}\right)$, higher water content will increase the latent heat of evaporation/pyrolysis considerably and significantly reduce the mass flux of combustibles, thus significantly reduce the HRR and the rate of fire spread. Further, vice versa, the dryer the combustibles, the faster and more intense the combustion and fire development becomes. 
It is therefore apparent that fires in dry homes will develop faster and represent a greater threat to people (and neighbor homes if windy) than a similar start fire when the fuel contains more moisture. The same holds for dry wildland fuel.

\subsection{Drying Dynamics}

Living plants and trees contain much water, often more than $100 \%$ mass of water per dry mass. Dead cellulose-based materials, e.g., wooden construction materials and dead wildland biomass, e.g., branches and litter, are still very hygroscopic. The humidity content is therefore a function of the relative humidity in the air in contact with the material, the exposure time as well as the previous sorption history [8]. At about 50\% relative humidity (RH), the equilibrium moisture content of dead wooden materials is typically about $10 \%$ mass of water per dry mass.

Drying processes of solids may be described by Fick's law, which in the one-dimensional case may be written as:

$$
\dot{m}_{w}^{\prime \prime}=-D_{\mathrm{w}} \cdot \mathrm{d} C / \mathrm{d} x\left(\mathrm{~kg} / \mathrm{m}^{2} \mathrm{~s}\right)
$$

where $\dot{m}_{w}^{\prime \prime}\left(\mathrm{kg} / \mathrm{m}^{2} \mathrm{~s}\right)$ is the mass flux of water, $D_{\mathrm{w}}\left(\mathrm{m}^{2} / \mathrm{s}\right)$ is the diffusion coefficient of water in the solid, $C\left(\mathrm{~kg} / \mathrm{m}^{3}\right)$ is the water concentration in the solid and $x(\mathrm{~m})$ is the distance. Ignoring minor changes in properties with changing fuel moisture content, the transient drying is given by:

$$
\frac{\partial C}{\partial t}=D_{\mathrm{W}} \cdot \nabla^{2} \mathrm{C}\left(\mathrm{kg} / \mathrm{m}^{3} \mathrm{~s}\right)
$$

where $t(\mathrm{~s})$ is the time.

The diffusion coefficient for water in dead wood, at concentrations well below the saturation concentration, is typically in the range $1-5 \times 10^{-10} \mathrm{~m}^{2} / \mathrm{s}$ [33]. Though expected to be in the same range, water diffusion coefficient for other wood-like materials may vary and should therefore be tested experimentally before any modeling. By solving Equations (4) and (5) for the correct diffusion coefficients, proper boundary conditions, including the solid-air interface and potential insolation, the drying processes can be modeled. This lays the foundation for assessing the fire risk related to the potential dead fuel low moisture content. It should be noted that this is more complicated for live fuels due to their possibility for accessing soil humidity.

\subsection{Dry Fuel Fire Risk}

The potential for developing a wooden home fire risk prediction model has principally been discussed by Metallinou and Log [34] and the risk may be represented as indicated in Figure 1.

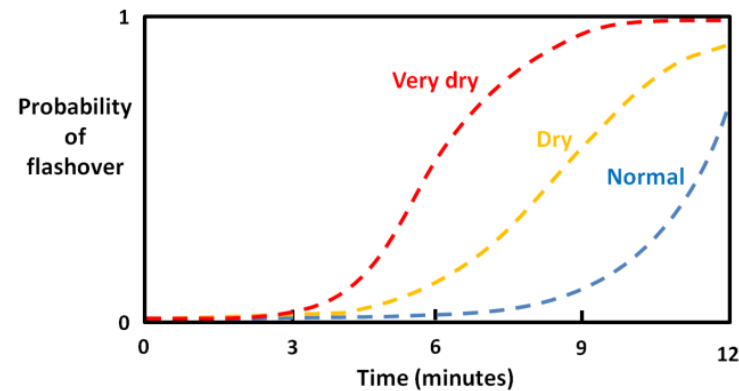

(a)

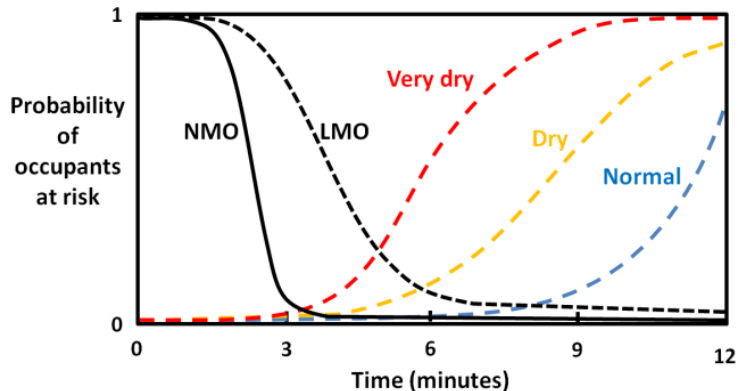

(b)

Figure 1. Principle sketches of probability of (a) flashover as a function time and (b) probability of occupants at risk, e.g., warned by a smoke detector, as a function of time for varying wood structure moisture contents. NMO: normal mobility occupants. LMO: low mobility occupants.

Modeling drying may be possible when the involved fuel characteristics are known together with the parameters influencing the drying process of dead fuel, e.g., construction wood and dead wildland 
fuel, and potential access to water for live plants. Weather forecasts then need to be known, both with respect to air temperature, air relative humidity, insolation, and wind conditions.

\section{Possibilities for Mitigating the Fire Disaster Risk}

\subsection{Fire Risk in Wooden Structure Environments}

Normally, a home represents a safe haven for its inhabitants. However, when involved in fire, a home may also be a severe threat to the inhabitants as well as to other homes through possible fire spread. The fire risk in a particular wooden home is not static. It is dependent on the activities within the home as well as incidents and conditions near the home, e.g., a fire in a neighbor home or a wildfire in the vicinity. The fire risk in the home, as well as the fire threat from the surrounding homes and wildland, is also dependent on the weather conditions rendering the home itself more or less susceptible to fire.

There is a number of potential ignition sources within a home today compared to a home 100 years ago. There have also been other gradual changes in ignition risk as well as introduction of upholstered furniture with highly combustible petroleum-based paddings. In cold climates, higher indoor temperature, and forced indoor ventilation without adjusting the indoor relative humidity (RH), makes the homes dryer and thereby more susceptible to fire. An aging population adds to this risk picture. Such gradual changes in the fire risk may be difficult to perceive, and their combined contribution may be difficult to comprehend.

Layer of protection analysis (LOPA) techniques, where the danger is placed in the center and "onion layers" protecting against the danger, are used in the process industries for determining the required number of independent protective barriers and their necessary safety integrity level $[35,36]$. A similar model may be considered for humans, as well as homes, at risk in fire scenarios, where the at-risk elements are placed in the center. An inverse LOPA inspired sketch of selected parameters influencing the fire risks analyzed in the present paper, including the different time scales, is presented in Figure 2.

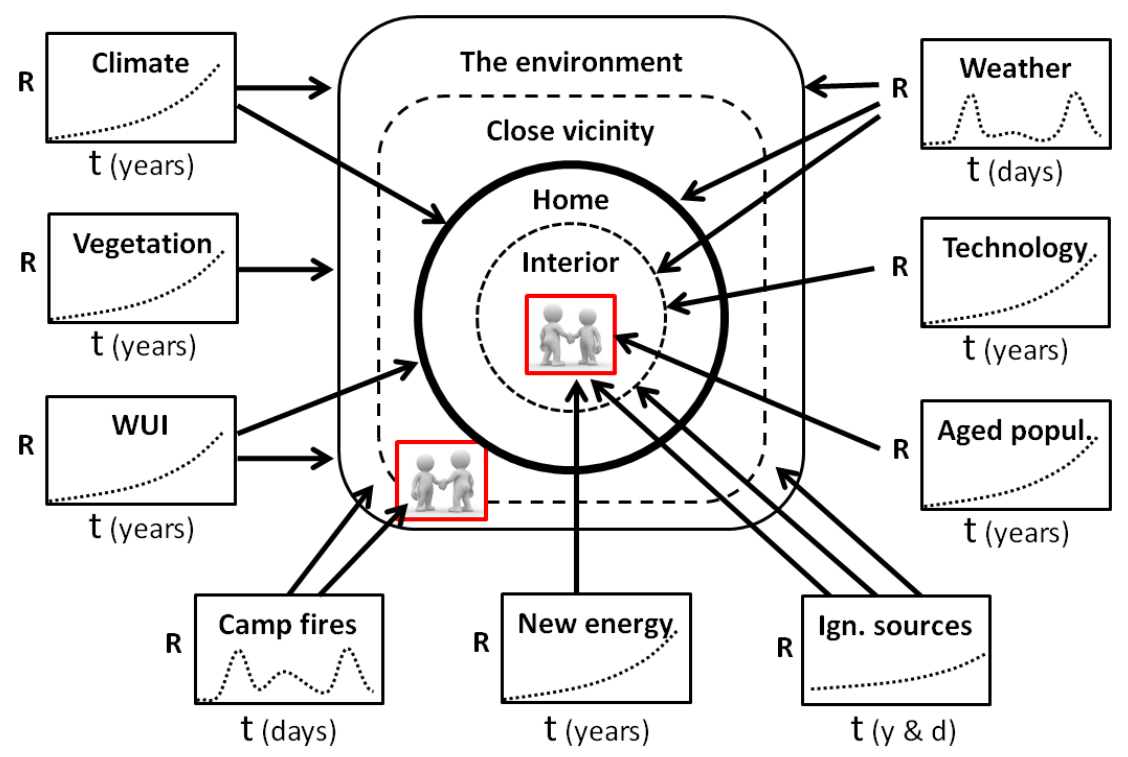

Figure 2. A simplified system of selected parameters influencing fire threat to humans and homes. $R=$ risk, $t=$ time (days, years).

Several of the dynamic risk contributions indicated in Figure 2 are quite difficult to alter, while others are easier to control or modify through, e.g., education, training, laws, and regulations. Some of the risk contributions are dependent on e.g., changes in weather conditions where the individual has no influence. However, since the weather may change rapidly from, e.g., warm and humid conditions 
to cold and dry conditions, the weather influence on fire risk in wooden structures may possibly be modeled [6].

The best way to prevent fire is to prevent ignition. It is generally known that dry wood burns better than more humid wood. It was, however, not generally understood by the Norwegian fire brigades that the conditions prior to, e.g., the town fire in Lærdalsøyri $[4,6]$ and the WUI fires in Flatanger and Frøya [4,37] (Figure 3), represented days of extreme peaks in fire risk. Understanding such risk peaks is a prerequisite for proper risk management. It is therefore evident that there is a need for a system informing the fire brigades and the public regarding days of potential extreme fire risk in single wooden structures as well as days where the risk of conflagration is very high. This could pave the road for informing the public as well as organizing emergency operations accordingly.

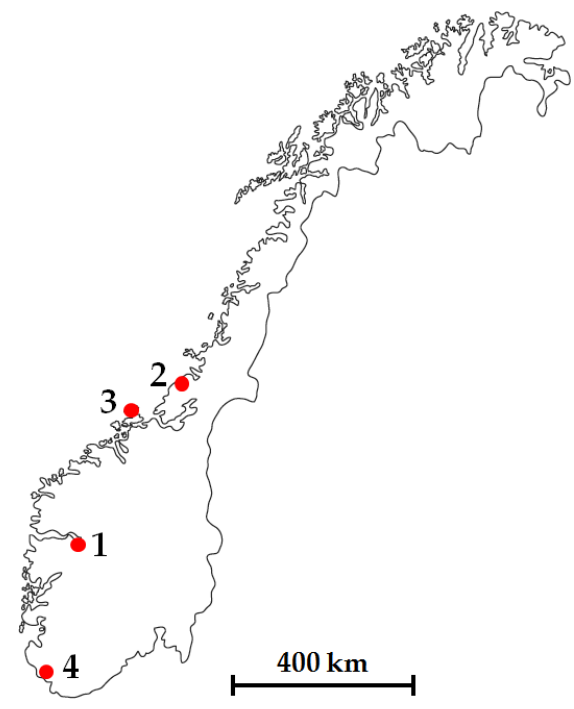

(a)

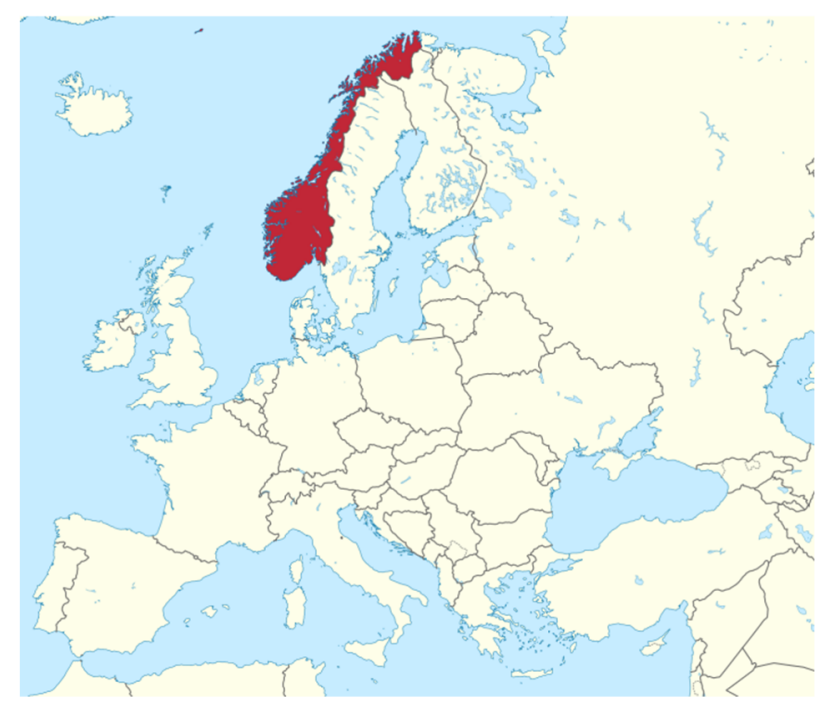

(b)

Figure 3. (a) Location of the Lærdalsøyri town fire, January 18-19, 2014 [4,6] (1) and location of the recent largest WUI fires in Norway, i.e., Flatanger $15 \mathrm{~km}^{2}$ (1500 ha), 28-31 January, 2014 (2), Frøya $10 \mathrm{~km}^{2}$ (1000 ha), 30-31 January, 2014 [4,37] (3) and Sokndal 7 km² (700 ha), 24-27 April, 2019 (4), which all started in and developed through old Calluna dominated coastal heathland. (b) Location of Norway in Europe.

\subsection{Calluna Dominated WUI Fire Risk}

Land-use adaptation can help mitigate WUI fire risk under current and future climate scenarios. The Atlantic heathlands of north-western Europe, from Portugal to the Arctic Circle, are part of an ancient cultural landscape that originated soon after the introduction of livestock husbandry. Anthropogenic fire regimes were used to increase pasture value and livestock production [38]. This has changed much during the past decades and most of the Calluna vulgaris heath has been left unmanaged. In these unmanaged old Calluna stands, the biomass accumulates, and the lower canopy consists mainly of dead branches [39] which dry very quickly [37,40]. Compared to young stands, much more intense fires are therefore experienced in 50+ years old stands currently representative for the coastal areas of Norway south of the Polar Circle [41]. Additionally, unmanaged Norwegian heathlands gradually develop a vegetation composition where e.g., juniper, pine and spruce increase in abundance. The highly flammable resinous juniper foliage contributes significantly to the fire prone biomass [42]. In coastal Norway, the Calluna stands were previously covered by snow during the winter months. However, as a result of global warming, this has changed through the last decades. For long periods during the recent winters, the ground has been snow-free, rendering the wildland susceptible to ignition and fire spread. A lack of land management (prescribed burning (PB) and 
grazing) in combination with climate changes therefore causes increasing concern, evidenced by the severe Flatanger wildfire January 2014 [37].

This is not just a modern European problem. The 1949 Mann Gulch fire, MT, USA, made immortal in the book "Young men and fire" by Maclean [43], was to a large extent a result of recent land-management changes. The area was a national park where herbivores were excluded the preceding year, resulting in waist high cured grass that supported dangerously rapid fire spread, killing 12 smokejumpers and one ranger.

Reestablishing PB with e.g., 10-20 years rotations and grazing can greatly reduce the WUI fire risk in Calluna dominated landscapes [44,45]. However, new and targeted prescribed burning regimes may be required in future climates, creating both new needs and opportunities for societal benefits in linking fire risk and land-use management science. This is also important regarding protection of cultural heritage buildings, e.g., remotely located Norwegian stave churches [46], exposed to potential wildfires.

Current warning systems do not predict cold climate wildfire risk. Previously developed wildfire warning models, e.g., the Canadian Forest Fire Weather Index (FWI) system, work very well for the fuel and temperature envelopes they are designed for. However, these models are not able to predict Calluna heathland sub-zero temperature fire risk. They do not predict the humidity levels in the lower canopy dead fuel [39], which has a significant bearing on the fire spread through a moisture content threshold [47]. Fundamental drying models are therefore required, but are not available today.

\subsection{Civic Groups for Fire Risk Management}

Local communities are a key to land-use and WUI fire risk management. In the Haugesund area, an innovative initiative from an informal farmer group (Lyngbrennarar på Haugalandet) has reestablished prescribed burning (PB) for better grazing and reduced WUI fire risk. This group has established contact with county and municipality officials, fire brigades, institutions supporting sustainable farming and academia. The group has a qualified approach, maintains dialog with the fire brigades when planning PBs and prioritizes personal safety. They have also optimized alternative equipment and approaches during PB fire control, for instance, leaf blowers and water mist blowers. This resembles civic initiatives regarding climate change [48] and is of particular interest from a societal WUI fire prevention perspective as it builds social capital and risk awareness [49-51]. Understanding this initiative and supporting their personal safety to prevent the loss of control and skin burns accidents is important [52-54]. Their field experience may be advantageous when developing fire characteristics models [55] and their organizational structure may be valuable for handling crisis situations [56-58]. Moreover, understanding their initiative may provide a model that can be transferred to other districts for the benefit of fire disaster risk reduction. There may also be possibilities for developing civic voluntary WUI fire control groups. Research indicates that such organizations may, when appropriate, include casual volunteers easier than formal response systems [59]. Hiker's safety is also of interest, both as potential starters of fires as well as victims of fire if caught in the wildland by an approaching fire, as indicated in Figure 2.

\subsection{Expected Climate Changes}

Both climate and weather drive the temporal variation in fire risk, resulting in greater fire risk under future climates. It is documented that fire development in structures is much faster when the involved wood is dry [60]. As indicated in Figure 1, in dry conditions the low mobility occupants are even more at risk than the normal population. They are also more at risk in WUI fires. This is expected to be an increasing challenge when elderly in increasing numbers are aging in place [61,62].

The risk contributing parameters presented in Figure 2 will change at different rates. Landscape succession, new home constructions in the WUI zone and more elderly staying at home, change on decadal timescales. Vegetation and wooden home fuel moisture content may change within a few days [8]. Wind strength and thin dead biomass moisture content may change within minutes (cured grass) and hours (twigs and thin branches) [37]. Keeping track of all these parameters is challenging. 
It is, however, necessary since, if aligned in an unfortunate combination in future climates, they may create a severe threat to life and property for extended periods. Identifying these critical contributions to the fire risk is essential.

\subsection{Risk Based Emergency Management?}

Risk awareness is a key to human responsiveness and safety [63]. A recent study of 26 Norwegian municipalities documents that, although the intentions of risk-based management has been required for 20+ years, it has not been practiced [64]. Vague risk representations or complicated disaster scenarios, e.g., the 2001 World Trade Center collapse [65] or the 2017 Grenfell Tower fire, UK [66], may be difficult to comprehend. Dry wood fire risk is easier to comprehend, and may represent a proper case for introducing risk-based emergency management. Suggestions for increasing risk understanding regarding dry home fires, i.e., to understand when fires develop fast and firefighter's turnout and driving time consumes more than the available time for controlling the fire, is outlined by Metallinou and Log [67].

The firefighter's preparedness may be increased by innovative practical training or low-cost simulations and serious games [68-70]. Calendar-based or predicted daily risk level-based spatial fleet allocations may be considered for optimal efficiency $[67,71]$. Otherwise, firefighters may arrive too late to handle the situation, as was the case in, e.g., the January 2014 Lærdal fire [6]. Fast developing fires may be included as shock-training where regular planning fails, and scenario-based interviews [72] may reveal opportunities regarding better emergency management [73,74]. The 2014 Lærdalsøyri and Flatanger fires $[8,36]$ represent cases where more use of fire dynamics theories in the operational area for low frequency long duration events could be beneficial [75].

Internationally, e.g., pipeline accidents have resulted in multiple fatalities. In Ghislenghien, Belgium, 30 July 2004, following a 45 min minor leak, a 70-bar pipeline ruptured, killed 24 people and hospitalized 150, most of whom sustained severe burns. To reduce such risk to the civilians and firefighters in Norway, a public warning system for pipeline leaks was recently developed, tested and optimized [76]. Similar public warning systems may be considered if a wooden town fire or a WUI fire is likely to escalate into a fire disaster.

\section{Suggested Research Agenda Framework}

\subsection{A Bow-Tie Framework}

During the last decades, factors influencing accident risk in the process industries have often been analyzed in bow-tie diagrams [77]. Factors influencing the incident likelihood (causes) are placed to the left and factors influencing possible outcomes (consequences) are placed to the right. The center part represents the top event, e.g., ignition. The bow-tie diagram is also valuable in communicating parameters and barriers influencing the likelihood of the top event as well as parameters and barriers mitigating further escalation of the incident. During the last decade, the bow-tie diagram has therefore been introduced as the main barrier model for international oil and gas companies as well as being introduced in e.g., the health sector [78].

The bow-tie approach may be interesting for presenting factors influencing wooden home fire risk, conflagrations in wooden villages and towns as well as WUI fire risk. For existing towns, the spatial layout is given, while changes such as densification of structures may increase the static fire risk. When designing new settlements, the layout may be optimized regarding e.g., WUI fire risk [24]. Land-use and land management influence succession and biomass accumulation. The likelihood of an ignition source to develop sustained burning is highly dependent on the fuel and the fuel moisture content (FMC). The FMC is a function of weather conditions, such as precipitation, temperature, relative humidity $(\mathrm{RH})$ and exposure time. Assuming than an ignition results in sustained burning, subsequent fire development is much faster when dry fuel is involved, and the fire spread rate is very dependent on the wind conditions. 
A bow-tie diagram may as well be constructed for vital parameters influencing fires with a focus on the presented research agenda. Ignition may be set as the top event, and a conflagration or a major WUI fire, both with potential for many fatalities and loss of many structures, may be set as the most severe outcome. An illustrative bow-tie diagram is presented in Figure 4, where the upper half represents fires in wooden structures and the lower half represents WUI fires. In the suggested bow-tie, prominent parameters are written in bold phase. This bow-tie diagram also represents a timeline, where the order of magnitude in the time scale is indicated. The factors to be analyzed in the proposed research agenda are marked green.

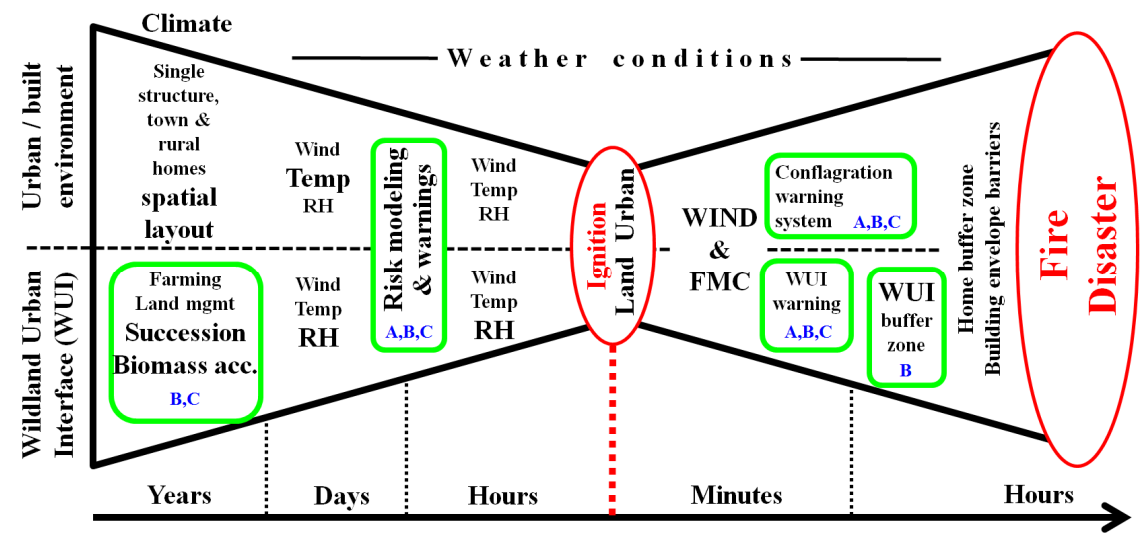

Figure 4. Bow-tie diagram for selected parameters influencing fire disaster risk, including examples of risk mitigating measures focused in the present study (marked green). Topics related to fire risk modeling and warning communication are marked A; topics related to WUI fire risk management are marked B; and topics related to risk based emergency planning and response are marked C.

The suggested approach establishes models for the dominant risk contributors, and how they may change for a given location in both long and short term. Examples may be decades of densification of built environments or succession of heathlands, to the time scale of days and hours for drying of wooden structures and dead wildland fuel. Based on these models, risk maps and warning systems for quickly changing temporal risk can likely be developed. Alongside such work, education and training in fire disaster risk concepts would be necessary. The way the current Norwegian performance-based fire safety regulations are interpreted may also be addressed to make the stakeholders realize that the suggested approach complies well with the requirements. When the risk is known and understood, risk reducing measures can be identified and prioritized to mitigate or control the risk. This includes, e.g., reducing the biomass in unmanaged heathlands, especially in the WUI zone, investigating the possibilities for risk-based emergency dimensioning, public warning systems, etc. However, these initiatives are significantly interlaced with each other and with the needs of the user groups. The following grouping may serve as a framework for differentiating the efforts required.

\subsection{Risk Modeling and Risk Warnings}

Challenges: There is currently no model for assessing the changes in fire susceptibility of inhabited wooden building settlements through the year. Available wildfire danger models are not sufficiently fundamental to handle Calluna heath fire risk and no current models predict high risk conditions in subzero temperatures.

Aim: Develop new, holistic models for dry fuel contribution to wooden homes fire risk, conflagration risk and degenerated heathland WUI fire risk, including landscape scenarios, under different weather conditions and changing climate.

Possible solution: From a theoretical viewpoint, transport phenomena and mathematics involved in heat transfer and drying are quite analogous, i.e., described by 2 nd order partial differential equations, with respective diffusion coefficients and boundary conditions. Since the heat equation, 
i.e., Equation (5), is well analyzed in the literature, and well known to the field of fire dynamics, with sound simplifications this can represent the basis for numerical modeling. The necessary theory and methodology can be developed and validated against observations, e.g., indoor relative humidity in homes and Calluna test sample mass loss under controlled conditions in a climate chamber. Based on the developed theory, weather recordings and weather forecast, methods for predicting the fuel moisture content in relevant fuel can be developed, both for wooden homes and for Calluna dominated heathland under different land-use regimes. These predictions can then be validated against future observations. A possible way forward for quantification of the risk may be to include the results as a separate module in a modified version of the Canadian FWI system designed for heathland shrub fuel, and in particular for the degenerated fire prone Calluna stands. Results from calibrated humidity sensors in representative homes spatially distributed can be used for model assessment regarding indoor relative humidity and fire growth rates in structures. Quantifying the risk may possibly be done by combining this knowledge with influence of wind speed, e.g., a power function, regarding the risk of fire spread between structures. Also in this case, the Canadian FWI system may serve as a conceptual design approach. When the models are sufficiently developed, it would be very valuable to test them for possibly future climates. Additional data and expertise from research in civil engineering and research on e.g., heathland fire danger rating in Scotland could add much value to the proposed research agenda. The associated conflagrations risk and WUI fire risk $48 \mathrm{~h}$ ahead could then be presented as envisioned in Figure 5.

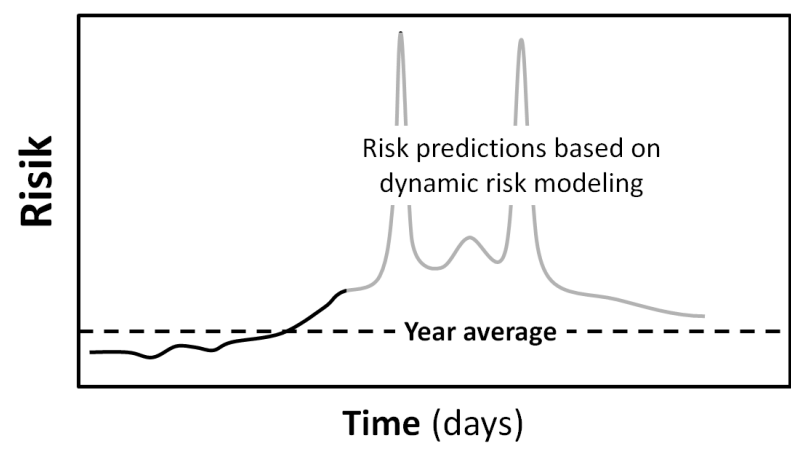

(a)
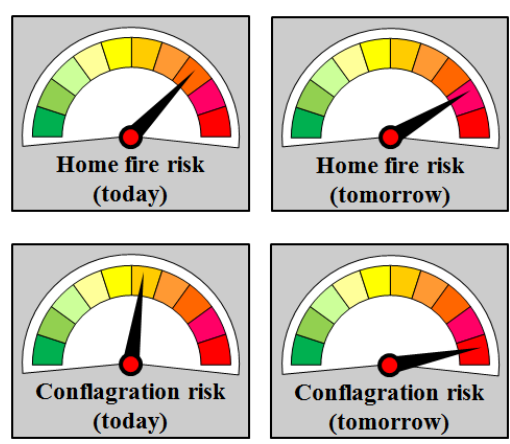

(b)

Figure 5. Conceptual risk representation graphics for (a) the next day(s) high risk conditions and (b) an example of wooden structure fire risk and conflagration risk.

\subsection{Adaptive Management of Calluna Heathland to Mitigate WUI Fire Risk}

Challenges: There is currently not sufficient knowledge about Calluna dominated heathland WUI fire risk in coastal Norway and no systematic approaches for evaluating and reducing this risk.

Aim: Empirically assess fire risk in response to secondary succession in coastal heathland landscapes; identify high WUI fire risk areas; and design fire breaks, e.g., by prescribed burning (PB) management strategies to reduce landscape-scale fire threat to wooden structures.

Suggested solution: The Calluna heathland biomass can be investigated for selected areas in a WUI fire risk perspective. The research can be based on established methods from plant ecology and fire dynamics to identify areas where the WUI risk should be reduced and land-use regimes optimized for fire risk control. Methodologies suggested by Mowery et al. [24] may by tested for the Norwegian coastal setting and adapted to the local conditions. Rules of thumb for evaluating WUI fire risk can be developed for e.g., firefighters to identify high risk zones. The spatial WUI fire risk can be investigated in selected fields, as well as at fields with known details about previous prescribed burnings (PB). Drying of test specimens from known age Calluna populations can provide input for the modelling and field studies can be undertaken to produce fire risk estimates (accumulated biomass and biomass type). Field studies can also be a part of the analysis of, and support to, the civic PB groups. Their activities during non-PB season can be studied when, and where, appropriate. Efficient ways to cooperate with, 
support and further develop civic PB groups can be identified based on organizational theories, e.g., group dynamics $[79,80]$. Semi-structured interviews [81,82] can be used to evaluate the development processes behind the civic PB groups and their hitherto self-directed learning processes [83]. These results can facilitate improved support and help spread their activities to areas susceptible to WUI fires. They may also be involved to supply valuable information to fire risk modeling based on their PBs [55]. Semi-structured interviews can also be used to analyze accidental ignition of WUI fires and loss of control in PB. Separate bow-tie model frameworks may be used for analyzing WUI buffer zones, and to communicate risk mitigating measures. Internationally recommended WUI fire risk reduction practices can be evaluated regarding local conditions and adapted, if applicable.

\subsection{Risk-Based Emergency Planning and Dimensioning}

Challenges: Risk management in Norwegian municipalities is generally not adjusted to highly dynamic variation in the risk picture along temporal (i.e., weather, see Figure 5) and spatial (i.e., WUI) dimensions. Firefighters generally do not consider dynamic risk variations during their training, or within their daily work routines.

Aim: Develop applications for WUI fire and conflagration risk warnings to enable risk-based proactive emergency planning and develop applications for public warnings and training tools for the emergency response system.

Possible solutions: Based on the results from developing risk modeling, warning systems and adaptive management of the WUI, internet-based applications that routinely update stakeholders regarding fire disaster risk can be developed. Based on interviews, potential costs and benefits of a proactive risk-based approach can be analyzed, and potential human, organizational, and technical obstacles and opportunities identified. Based on predicted risk, virtual reality scenarios for training emergency response teams can be developed and tested in pilot studies. Communication with the personnel developing risk modeling and warning systems, and adaptive management of the WUI, is needed to optimize approaches and progress with partner practitioners. New models for organizing emergency responses, i.e., proactive responses based on risk prediction models in time and space can be investigated and tested by partner fire brigades. Within the scope of the suggested research agenda, the ALARP (as low as reasonably practicable) principle, originating from the coal mining industry [77] and adapted by the oil and gas industry $[78,84]$, can be tested to investigate whether this can stimulate to societal risk reduction beyond the prevailing acceptance levels. Warnings issued to fire brigades and the public can be tested locally.

\subsection{Required Fields of Expertise and Research Cooperation}

The suggested research agenda is highly interdisciplinary. To name a few fields of expertise, personnel within fire safety, vegetation ecology, societal safety, computer science, emergency management, and adult learning processes would be beneficial to establish a robust research consortium. It would also be wise to include personnel with experience from other regions, especially those that are more frequently associated with fire disasters, e.g., USA, Canada, Australia or the Mediterranean area. For improved networking, participation in international work groups on fire disaster prevention would be very beneficial for sharing ideas and research findings. This could e.g., be the IAFSS Large Outdoor Fires \& the Built Environment (LOFBE) Working Group and the European Cooperation in Science and Technology (COST) initiative FIRElinks.

\subsection{Stakeholder Involvement}

In order to ensure stakeholder involvement, a "participatory research" approach, whereby researchers and administrators/managers, policy makers, farmers and firefighters, and their officers can interact may be beneficial. National and regional level public safety administrators can be invited to workshops to discuss possible adjustments to management guidelines for dynamic fire risk assessment and proactive emergency planning. The participants' professional networks can be 
used to communicate findings and promote implementation of research findings. Participation in new networks such as the IAFSS LOFBE and the COST FIRElinks may be very beneficial for the stakeholders to gain trust in, give support to and take ownership in the proposed research agenda. When risk mitigation measures are identified, locally adapted society protection programs similar to FireWise and FireSmart should be considered. Based on case studies and general experiences from Canada, USA and Australia [18-21], and documented reduction in losses [22], it will be easier to organize successful research campaigns and get the necessary stakeholder involvement.

\section{Discussion}

In the present work, the fire risk to people and homes are viewed as a LOPA inspired system with layers of protection and a number of parameters influencing the fire risk, both temporarily and spatially. Taking Norway as an example, we have shown how to explore if and how the increasing fire incidence can be linked to concomitant changes in climate, land-use, and habitat management. Further, we have suggested how to develop new, dynamic, and adaptive fire risk assessment and management tools. In particular, the focus was temporal changes in fire risk in wooden structure settlements and coastal WUI areas in Norway. At first, this may seem to be a strange combination. However, in the recent study by Mowery et al. [24], they make it clear that structures should be considered as fuel themselves and they give several examples where WUI fires transferred to the built environment conflagrations. They also highlight that it may be the other way around, i.e., a building fire that starts a wildland fire exposing other WUI areas.

The simplified LOPA-inspired sketch of parameters influencing the threat to humans and homes, i.e., Figure 2, is intended to make it easier to understand that a number of parameters influence the fire risk. It also presents the highly different timescales, from decades to hours, clearly showing that the fire disaster risk is not constant. The sketch indicates that some of the parameters affect the home as a protection system, while some parameters also influence the home itself and its susceptibility to fire. In a situation where each of the risk contributing parameters vary, at vastly different time scales, we believe that a representation like Figure 2 makes it easier to understand which parameters can be controlled and which can only be monitored/predicted for danger warnings and possibly proactive emergency planning.

A bow-tie diagram, inspired by similar barrier models as used in the industry and health sectors, is presented for selected parameters influencing the fire disaster risk, i.e., Figure 4. The bow-tie contains both urban and WUI fire risk. The top event is ignition, and the prominent parameters are emphasized according to their influence on the fire development. The developed bow-tie also presents a nonlinear time scale towards a possible devastating fire disaster clearly marked on the right side of the model. A bow-tie with a fire disaster end point, as well as a clear chronology has not been found in any previous literature. We believe that this representation provides the readers information about the complexity involved, but also insight in the parameters that can be managed to reduce the risk.

The main challenges, as seen from the perspective of coastal Norwegian wooden town areas and rural settlements, are related to:

- risk modeling and risk warnings,

- adaptive management of Calluna heathland to mitigate WUI fire risk,

- $\quad$ risk-based emergency planning and dimensioning,

- $\quad$ in addition to stakeholder involvement.

Aims for each challenge are stated and possible solutions to these challenges are suggested, and will be briefly discussed.

Based on previous analysis [34], modeling the important parameters regarding the contribution of dry wooden home fire risk should be possible. Previous work on heathland $[40,41]$ and drying of degenerated (dead) Calluna plants [37] indicate that it should also be possible to develop and communicate degenerated heathland fire danger warnings. In a recent study, Keeley and Syphard [12] 
showed that for fires in California, fuel-dominated versus wind-dominated wildfires had very different outcomes. In the presented bow-tie, wind strength and fuel moisture content are given significant weight. To fully include both in a fire risk model may be challenging, e.g., weighting may be an issue [31]. However, if difficult to include, the wind strength forecast may be taken as an independent risk parameter, to be evaluated and presented separately in the risk warnings.

To empirically assess fire risk in response to secondary succession in coastal heathland should be possible based on e.g., the accumulated elevated biomass and the fraction of dead versus live biomass. It is quite likely that rule of thumb methods may be developed to distinguish between e.g., low, medium and high risk related to secondary succession and biomass accumulation $[40,44]$. In particular, the juniper (Juniperus communis) makes a considerable contribution to fire spread with its very flammable resinous foliage [42]. When high WUI fire risk areas are identified, the possibilities of arranging fire breaks can be evaluated in locations where natural fire breaks, e.g., naked rock, lakes or fjords, can be utilized as part of larger continuous firebreak systems.

Prescribed burning may be one of the many possibilities to reduce landscape-scale fire threat to wooden structures [24]. It is quite likely that civic groups performing prescribed burning of Calluna dominated areas to re-establish the several thousand years old heathland management regime are supportive to the proposed research agenda. Academic attention and guidance in fire safety has thus far been welcomed by these groups as well as by the local fire brigades.

Regarding WUI fire risk, keeping the heathland in healthy conditions is beneficial for agricultural activities, e.g., herbivore and honey production, as well as for tourism and recreational purposes. The colorful heathland in flowering condition is indeed a spectacle. Thus, in addition to fire disaster prevention, i.e., focusing on saving lives and property, the proposed research agenda can demonstrate added value in several ways giving a diversity of societal benefits, including protection of an endangered habitat [85]. By aiming outside the traditional firefighting and rescue field, more stakeholders may identify with, support and take ownership in the suggested research. This could be very beneficial for the main purpose of the research agenda, i.e., fire disaster prevention [24]. The developed bow-tie indicates that measures implemented can prevent fire disasters many years into the future. Some of these measures may not be very costly, and thus give a high cost benefit ratio when considered from a long-term perspective, i.e., decades.

Norway is a quite small country where interdisciplinary cooperation on the principle of "dugnad" (volunteer community cooperation and participation) brings together people of different knowledges and skills to reach common goals [86]. Since several disciplines and parties have a common goal regarding fire disaster prevention, it is likely that the "dugnad" mentality will strengthen the research cooperation as well as the involvement of user group representatives. Innovation is required for solving new challenges, and is best fostered in groups with ambitious and highly imaginative individuals who manage to create positive working environments characterized by support and common goals [87], and generally stimulated by interdisciplinary teams [88,89]. Setting up a team of researchers from highly different fields, together with various stakeholders, all sharing the same goal, seems promising and should be aimed at for stimulating the innovation processes needed for reduced fire disaster risk.

The suggested research agenda indirectly deals with people by aiming to provide information about situations of increased fire disaster risk and by informing about a developing crisis situation if a fire has started and may develop into a fire disaster. This may lead to the fire disasters being prevented. The location of buildings, both in town areas and in the WUI, has already been planned, and is given from the perspective of the current paper. However, planning with respect to potential severe fires comes into play regarding, e.g., prescribed burning, proactive emergency organizing, as well as what people plant in their gardens [90]. This results in better protection as e.g., WUI fires become easier to control when the fire fighters arrive earlier at a fire scene. In the suggested research agenda, the drying of potential fuel (wildland fuel and wooden homes) and wind conditions should be modeled for risk prediction. Information of the predicted fire risk should be communicated to fire brigades, homeowners and the public. It is believed that the suggested interdisciplinary research 
approach, at least in part dealing with all the important " $\mathrm{P}$ "s [12], may become successful compared to approaches where only a minor fraction of the characteristic bow-tie is investigated. Committing to the suggested research agenda is therefore expected to contribute to the recent fire research within, e.g., multi-risk assessment [91], socioeconomic changes [92,93], forest fire danger rating prediction [94,95], land-use [96], and social vulnerability [97].

Author Contributions: Conceptualization, T.L. and M.-M.M.; methodology, T.L., M.-M.M., V.V. and L.G.V.; validation, V.V. and L.G.V.; formal analysis, T.L., V.V., L.G.V. and M.-M.M.; investigation, T.L. and V.V.; resources, T.L.; writing—original draft preparation, T.L. and M.-M.M.; writing—review and editing, T.L., V.V., L.G.V. and M.-M.M.; visualization, T.L.; project administration, M.-M.M.; funding acquisition, T.L. All authors have read and agreed to the published version of the manuscript.

Funding: The writing of the paper was supported by the Research Council of Norway, grant no 298993.

Acknowledgments: The enthusiasm and many fruitful discussions with local fire brigades and the prescribed burner group Lyngbrennarar på Haugalandet are much appreciated. The improvements of the original manuscript suggested by the anonymous reviewers are also much appreciated.

Conflicts of Interest: The authors declare no conflict of interest.

\section{References}

1. Scott, A.C.; Bowman, D.M.J.S.; Bond, W.J.; Pyne, S.J.; Alexander, M.E. Fire on Earth: An Introduction; John Wiley \& Sons: West Sussex, UK, 2014.

2. Losnegård, G. Norske Ulykker og Katastrofar; Skald: Leikanger, Norway, 2013.

3. Pirsko, A.R.; Fons, W.L. Frequency of Urban Building Fires as Related to Daily Weather Conditions; Interim Technical Report, 866; US Dep. of Agriculture: Washington, DC, USA, 1956.

4. DSB. Brannene i Lærdal, Flatanger og på Frøya Vinteren 2014; Norwegian Directorate for Civil Protection: Tønsberg, Norway, 2014.

5. Steen-Hansen, A.; Bøe, G.A.; Hox, K.; Mikalsen, R.F.; Stensaas, J.P.; Storesund, K. Evaluation of fire spread in the large Lærdal fire, January 2014. In Proceedings of the 14th International Fire and Materials Conference and Exhibition, San Francisco, CA, USA, 2-4 February 2015; pp. 1014-1024.

6. Log, T. Cold Climate Fire Risk; A Case Study of the Lærdalsøyri Fire, January 2014. Fire Technol. 2016, 52, 1825-1843. [CrossRef]

7. Delâge, C. Rapport du Commissaire Aux Incendies du Québec. Rapport du Commissaire Aux Incendies du Québec. 2015. Available online: http://www.coroner.gouv.qc.ca/fileadmin/Coroners/Rapport_d_enquete_-_L. _Isle-Verte.pdf (accessed on 14 March 2018).

8. Log, T. Indoor relative humidity as a fire risk indicator. Build. Environ. 2017, 111, 238-248. [CrossRef]

9. Liu, D.; Xu, Z.; Fan, C. Predictive analysis of fire frequency based on daily temperatures. Nat. Hazards 2019, 97, 1175-1189. [CrossRef]

10. Blanchi, R.; Leonard, J.; Haynes, K.; Opie, K.; James, M.; de Oliveira, F.D. Environmental circumstances surrounding bushfire fatalities in Australia 1901-2011. Environ. Sci. Policy 2014, 37, 192-203. [CrossRef]

11. Rego, F.M.C.C.; Rodríguez, J.M.M.; Calzada, V.R.V.; Xanthopoulos, G. Forest Fires—Sparking Firesmart Policies in the EU; Publications Office of the European Union: Brussels, Belgium, 2018.

12. Keeley, J.E.; Syphard, A.D. Twenty-first century California, USA, wildfires: Fuel-dominated vs. wind-dominated fires. Fire Ecol. 2019, 15, 24. [CrossRef]

13. Hardy, K.; Comfort, L.K. Dynamic decision processes in complex, high-risk operations: The Yarnell Hill Fire, June 30, 2013. Saf. Sci. 2015, 71, 39-47. [CrossRef]

14. Simms, C.D. Canada's Fort McMurray fire: Mitigating global risks. Lancet Glob. Health 2016, 48 , e520. [CrossRef]

15. Boustras, G.; Boukas, N. Forest fires' impact on tourism development: A comparative study of Greece and Cyprus. Manag. Environ. Qual. 2013, 24, 498-511. [CrossRef]

16. San-Miguel-Ayanz, J.; Durrant, T.; Boca, R.; Libertà, G.; Branco, A.; de Rigo, D.; Ferrari, D.; Maianti, P.; Vivancos, T.A.; Oom, D.; et al. Forest Fires in Europe, Middle East and North Africa 2018; Publications Office of the European Union: Brussels, Belgium, 2019. 
17. Uhr, C.; Lindgren, J.; Holmberg, M.; Bynander, F.; Koelga, S.; Johansson, B.J.E. Once upon a time in Västmanland - the power of narratives or how the "truth" unfolds. In Proceedings of the13th International Conference on Information Systems for Crisis Response and Management, Rio de Janeiro, Brazil, 22-25 May 2016.

18. Kramer, H.A.; Mockrin, M.H.; Alexandre, P.M.; Stewart, S.I.; Radeloff, V.C. Where wildfires destroy buildings in the US relative to the wildland-urban interface and national fire outreach programs. Int. J. Wildland Fire 2018, 27, 329-341. [CrossRef]

19. McGee, T.K. Public engagement in neighbourhood level wildfire mitigation and preparedness: Case studies from Canada, the US and Australia. J. Environ. Manag. 2011, 92, 2524-2532. [CrossRef]

20. Olsen, C.S.; Kline, J.D.; Ager, A.A.; Olsen, K.A.; Short, K.C. Examining the influence of biophysical conditions on wildland-urban interface homeowners' wildfire risk mitigation activities in fire-prone landscapes. Ecol. Soc. 2017, 22, 21. [CrossRef]

21. Paveglio, T.B.; Kelly, E. Influences on the Adoption and Implementation of a Wildfire Mitigation Program in an Idaho City. J. For. 2018, 116, 47-54. [CrossRef]

22. Labossière, L.M.M.; McGee, T.M. Innovative wildfire mitigation by municipal governments: Two case studies in Western Canada. Int. J. Disaster Risk Reduct. 2017, 22, 204-210. [CrossRef]

23. Manzello, S.L.; Foote, E.I.D. Characterizing Firebrand Exposure from Wildland-Urban Interface (WUI) Fires: Results from the 2007 Angora Fire. Fire Technol. 2014, 50, 105-124. [CrossRef]

24. Mowery, M.; Read, M.; Johnston, K.; Wafaie, T. Planning the Wildland-Urban Interface, Report 594; Planning Advisory Service, American Planning Association: Washington, DC, USA, 2019.

25. Bento-Gonçalves, A.; Vieira, A. Wildfires in the wildland-urban interface: Key concepts and evaluation methodologies. Sci. Total Environ. 2019, 707, 135529. [CrossRef] [PubMed]

26. Badia, A.; Pallares-Barbera, M.; Valldeperas, N.; Gisbert, M. Wildfires in the wildland-urban interface in Catalonia: Vulnerability analysis based on land use and land cover change. Sci. Total Environ. 2019, 673, 184-196. [CrossRef] [PubMed]

27. Suzuki, S.; Manzello, S.L. Characteristics of Firebrands Collected from Actual Urban Fires. Fire Technol. 2018, 54, 1533-1546. [CrossRef]

28. Suzuki, S.; Manzello, S.L. Understanding structure ignition vulnerabilities using mock-up sections of attached wood fencing assemblies. Fire Mater. 2019, 43, 675-684. [CrossRef]

29. Manzello, S.L.; Bianchi, R.; Gollner, M.J.; Gorham, D.; McAllister, S.; Pastor, E.; Planas, E.; Reszeka, P.; Susuki, S. Summary of workshop large outdoor fires and the built environment. Fire Saf. J. 2018, 100, 76-92. [CrossRef]

30. Manzello, S.L.; McAllister, S.; Suzuki, S. Large out-door fires and the built environment: Objectives and goals of permanent IAFSS working Group. Fire Technol. 2018, 54, 579-581. [CrossRef]

31. Alexander, D.; Barbat, A.; Carreño, M.L.; Kienberger, S.; Miniati, R.; Welle, W.; Zaidi, R.Z.; Tedim, F.; Vinchon, C.; Manuel Garcin, M.; et al. Methods for the Improvement of Vulnerability Assessment in Europe; Collaborative Project No. 211590 Report; European Commission: Brussels, Belgium, 2011.

32. Babrauskas, V.; Peacock, R. Heat Release Rate: The Single Most Important Variable in Fire Hazard. Fire Saf. J. 1992, 18, 255-272. [CrossRef]

33. Baronas, R.; Ivanauskasa, F.; Juodeikienèc, I.; Kajalavičiusc, A. Modelling of Moisture Movement in Wood during Outdoor Storage. Nonlinear Anal. Model. Control 2001, 6, 3-14. [CrossRef]

34. Metallinou, M.M.; Log, T. Cold Climate Structural Fire Danger Rating System? Challenges 2018, 9, 12. [CrossRef]

35. Dowell, A.M. Layer of protection analysis for determining safety integrity level. ISA Trans. 1998, 37, 155-165. [CrossRef]

36. Willey, R.J. Layer of Protection Analysis. Procedia Eng. 2014, 84, 12-22. [CrossRef]

37. Log, T.; Thuestad, G.; Velle, L.G.; Khattri, S.K.; Kleppe, G. Unmanaged heathland-a fire risk in subzero temperatures? Fire Saf. J. 2017, 90, 62-71. [CrossRef]

38. Webb, N.R. The traditional management of European heathlands. J. Appl. Ecol. 1998, 35, 987-990. [CrossRef]

39. Davies, G.M.; Legg, J.J.; O’hara, R.; MacDonals, A.J.; Smith, A.A. Winter desiccation and rapid changes in the live fuel moisture content of Calluna vulgaris. Plant Ecol. Divers. 2010, 3, 289-299. [CrossRef] 
40. Velle, L.G.; Haugum, S.V.; Log, T.; Thorvaldsen, P.; Thuestad, G.; Vandvik, V. New perspectives on heathland management under influence of extreme winter droughts. In Proceedings of the 15th European Heathland Workshop. Lowland Heaths under Pressure: Challenges in Ecological Restoration, Nijmegen, The Netherlands, 25 August 2017.

41. Nilsen, L.S.; Johansen, L.; Velle, L.G. Early stages of Calluna vulgaris regeneration after burning of coastal heath in central Norway. Appl. Veg. Sci. 2005, 8, 57-64. [CrossRef]

42. Diotte, M.; Bergeron, Y. Fire and the distribution of Juniperus communis L. in the Boreal Forest of Quebec, Canada. J. Biogeogr. 1989, 16, 91-96. [CrossRef]

43. Maclean, N.F. Young Men and Fire; The Univ. Chicago Press: Chicago, IL, USA, 1992.

44. Kaland, P.E. The origin and management of Norwegian coastal heaths as reflected by pollen analysis. In Anthropogenic Indicators in Pollen Diagrams, Behre, K.E., Ed.; Balkema: Rotterdam, The Netherlands, 1986; pp. 19-36. [CrossRef]

45. Velle, L.G.; Vandvik, V. Succession after prescribed burning in coastal Calluna heathlands along a 340-km latitudinal gradient. J. Veg. Sci. 2014, 25, 546-558. [CrossRef]

46. Log, T.; Cannon-Brookes, P. 'Water Mist' for Fire Protection of Historic Buildings and Museums. Mus. Manag. Curatorship 1995, 13, 283-298. [CrossRef]

47. Davies, G.M.; Legg, C.J. Fuel moisture thresholds in flammability of Calluna vulgaris. Fire Technol. 2011, 47, 421-436. [CrossRef]

48. Cloutier, G.; Papin, M.; Bizier, C. Do-it-yourself (DIY) adaptation: Civic initiatives as drivers to address climate change at the urban scale. Cities 2018, 74, 284-291. [CrossRef]

49. Bihari, M.; Ryan, R. Influence of social capital on community preparedness for wildfires. Landsc. Urban Plan. 2012, 106, 253-261. [CrossRef]

50. Paveglio, T.B.; Nielsen-Pincus, M.; Abrams, J.; Mosseley, C. Advancing characterization of social diversity in the wildland-urban interface: An indicator approach for wildfire management. Landsc. Urban Plan. 2017, 160, 115-126. [CrossRef]

51. Whittaker, J.; McLennan, B.; Handmer, J. A review of informal volunteerism in emergencies and disasters: Definition, opportunities and challenges. Int. J. Disaster Risk Reduct. 2015, 13, 358-368. [CrossRef]

52. Moi, A.L.; Haugsmyr, E.; Heisterkamp, H. Long-Term Study of Health and Quality of Life after Burn Injury. Ann. Burns Fire Disasters 2016, 29, 295-299.

53. Log, T. Modeling burns for pre-cooled skin flame exposure. Int. J. Environ. Res. Public Health 2017, 14, 1024. [CrossRef]

54. Log, T.; Moi, A.L. Ethanol and Methanol Burn Risks in the Home Environment. Int. J. Environ. Res. Public Health 2018, 15, 2379. [CrossRef]

55. Davies, G.M.; Legg, C.J.; Smith, A.A.; MacDonald, A. Development and participatory evaluation of fireline intensity and flame property models for managed burns on Calluna-dominated heathlands. Fire Ecol. 2019, 15, 30. [CrossRef]

56. Johannessen, I.; McArthur, P.W.; Jonassen, J.R. Informal leadership redundancy: Balancing structure and flexibility in subsea operations. Scand. J. Manag. 2015, 31, 409-423. [CrossRef]

57. Johansson, R.; Danielsson, E.; Kvarnlöf, L.; Eriksson, K.; Karlsson, R. At the external boundary of a disaster response operation: The dynamics of volunteer inclusion. J. Contingencies Crisis Manag. 2018, 26, 519-529. [CrossRef]

58. Darkow, P.M. Beyond 'bouncing back': Towards an integral, capability-based understanding of organizational resilience. J. Contingencies Crisis Manag. 2018, 27, 145-156. [CrossRef]

59. Skar, M.; Sydnes, M.; Sydnes, A.K. Integrating unorganized volunteers in emergency response management: A case study. Int. J. Emerg. Ser. 2016, 5, 52-65. [CrossRef]

60. Kraaijeveld, A.; Gunnarshaug, A.; Schei, B.; Log, T. Burning rate and time to flashover in wooden 1/4 scale compartments as a function of fuel moisture content. In Proceedings of the 8th International Fire Science \& Engineering Conference, Interflam 2016, Windsor, UK, 4-6 July 2016; pp. 553-558.

61. Götmark, F.; Cafaro, P.; O'Sullivan, J. Aging Human Populations: Good for Us, Good for the Earth. Trends Ecol. Evol. 2018, 33, 851-862. [CrossRef]

62. Jansen, W.J.; Wilson, R.S.; Visser, P.J.; Nag, S.; Schneider, J.A.; James, B.D.; Leurgans, S.E.; Capuano, A.W.; Bennett, D.A.; Boyle, P.A. Age and the association of dementia-related pathology with trajectories of cognitive decline. Neurobiol. Aging 2018, 61, 138-145. [CrossRef] 
63. Westcott, R.; Ronan, K.; Bambrick, H.; Taylor, M. Public health and natural hazards: New policies and preparedness initiatives developed from an Australian bushfire case study. Aust. N. Z. J. Public Health 2019, 43, 395-400. [CrossRef]

64. Njå, O.; Vastveit, K.R. Norske Kommuners Planlegging, Gjennomføring og Bruk av Risiko- og Sårbarhetsanalyser $i$ Forbindelse med Samfunnssikkerhetsarbeidet; University of Stavanger: Stavanger, Norway, 2016.

65. Torero, J.L. Fire-induced structural failure: The World Trade Center, New York. For. Eng. 2011, 164, 69-77. [CrossRef]

66. Potton, E. Grenfell Tower Fire: Background. In House of Commons Briefing Paper; CBP: Washington, DC, USA, 2018.

67. Metallinou, M.M.; Log, T. Health Impacts of Climate Change-Induced Subzero Temperature Fires. Int. J. Environ. Res. Public Health 2017, 14, 814. [CrossRef]

68. Williams-Bell, F.M.; Kapralos, B.; Hogue, A.; Murphy, B.M.; Weckman, E.J. Using serious games and virtual simulation for training in the fire service: A review. Fire Technol. 2015, 51, 553-584. [CrossRef]

69. Heldal, I.; Wijkmark, C.H.; Pareto, L. Simulation and serious games for firefighter training: Challenges for effective use. NOKOBIT 2016, 24, 12.

70. Heldal, I.; Wijkmark, C.H. The ROI of Simulation-Based Training vs. Live Training of Fire Commanders. In Proceedings of the International Forum for the Military and Civil Simulation, Training and Education Community (ITEC), Stockolmsmässan, Sweden, 14-16 May 2019.

71. Pérez, J.; Maldonado, S.; López-Ospina, H. A fleet management model for the Santiago fire department. Fire Saf. J. 2016, 82, 1-11. [CrossRef]

72. Sampson, H.; Johannessen, I.A. Turning on The Tap: The benefits of using 'real-life' vignettes in qualitative research interview. Qual. Res. 2020, 20, 56-72. [CrossRef]

73. Metallinou, M.M. Liquefied Natural Gas as a New Hazard; Learning Processes in Norwegian Fire Brigades. Safety 2019, 5, 11. [CrossRef]

74. Sommer, M.; Njå, O. Learning amongst Norwegian fire-fighters. J. Workp. Learn. 2011, 23, 435-455. [CrossRef]

75. Johansson, N.; Svensson, S. Review of the Use of Fire Dynamics Theory in Fire Service Activities. Fire Technol. 2019, 55, 81-103. [CrossRef]

76. Metallinou, M.M. Single- and double-loop organi-zational learning through a series of pipeline emergency exercises. J. Contingencies Crisis Manag. 2018, 26, 530-543. [CrossRef]

77. Andonov, S. Bowtie Methodology: A Guide for Practitioners; CRC Press: Boca Raton, FL, USA, 2018.

78. McLeod, R.W.; Bowie, P. Bowtie Analysis as a prospective risk assessment technique in primary healthcare. Policy Pract. Health Saf. 2018, 16, 177-193. [CrossRef]

79. Tuckman, B.W. Developmental sequence in small groups. Psychol. Bull. 1965, 53, 384-399. [CrossRef]

80. Bonebright, D.A. 40 years of storming: A historical review of Tuckman's model of small group development. Hum. Resour. Dev. Int. 2010, 13, 111-120. [CrossRef]

81. Gilham, B. Research Interviews, the Range of Techniques; McGraw-Hill Education: London, UK, 2005.

82. Kvale, S. Interviews. An Introduction to Qualitative Research Interviewing, 2nd ed.; Sage Publications: Thousand Oaks, CA, USA, 2004.

83. Tough, A. The Adult's Learning Projects, A Fresh Theory and Practice in Adult Learning; The Ontario Institute for Studies in Education: Toronto, ON, Canada, 1971.

84. UK Court of Appeal. Edwards Versus National Coal Board; Croner-i: London, UK, 1949.

85. Jones-Lee, M.; Aven, T. ALARP—what does it really mean? Reliab. Eng. Sys. Saf. 2011, 96, 877-882. [CrossRef]

86. Kaland, P.E.; Kvamme, M. Kystlyngheiene i Norge-Kunnskapsstatus og Beskrivelse av 23 Referanseomrader. (Coastal Heathlands in Norway_Descriptions of 23 Reference Areas); Norwegian Environment Agency: Trondheim, Norway, 2013.

87. Nygaard, J. Local, Open-Air Performances in Norway as Interdisciplinary Theatre. Theatre Res. Int. 2001, 26, 172-180. [CrossRef]

88. Mathisen, G.E. Climates for Creativity and Innovation: Definitions, Measurement, Predictors, and Consequences. Ph.D. Thesis, University of Bergen, Bergen, Norway, 2005.

89. Forsth, L.-R. Praktisk Nytenkning. Systematisk og Kreativ Problemløsning; Aquarius: Oslo, Norway, 2014.

90. Brad, R.; Murray, B.R.; Martin, L.J.; Brown, C.; Phillips, M.L. Selecting Low-Flammability Plants as Green Firebreaks within Sustainable Urban Garden Design. Fire 2018, 1, 15. [CrossRef] 
91. Pilone, E.; Demichela, M.; Baldissone, G. The Multi-Risk Assessment Approach as a Basis for the Territorial Resilience. Sustainability 2019, 11, 2612. [CrossRef]

92. Carlucci, M.; Zambon, I.; Colantoni, A.; Salvati, L. Socioeconomic Development, Demographic Dynamics and Forest Fires in Italy, 1961-2017: A Time-Series Analysis. Sustainability 2019, 11, 1305. [CrossRef]

93. Martinho, V.J.P.D. Socioeconomic Impacts of Forest Fires upon Portugal: An Analysis for the Agricultural and Forestry Sectors. Sustainability 2019, 11, 374. [CrossRef]

94. Varela, V.; Vlachogiannis, D.; Sfetsos, A.; Karozis, S.; Politi, N.; Giroud, F. Projection of Forest Fire Danger due to Climate Change in the French Mediterranean Region. Sustainability 2019, 11, 4284. [CrossRef]

95. Wang, L.; Zhao, Q.; Wem, Z.; Qu, J. RAFFIA: Short-term Forest Fire Danger Rating Prediction via Multiclass Logistic Regression. Sustainability 2018, 10, 4620. [CrossRef]

96. Marchi, M.; Chianucci, F.; Ferrara, C.; Pontuale, G.; Pontuale, E.; Mavrakis, A.; Morrow, N.; Rossi, F.; Salvati, L. Sustainable Land-Use, Wildfires, and Evolving Local Contexts in a Mediterranean Country, 2000-2015. Sustainability 2018, 10, 3911. [CrossRef]

97. Lidskog, R. Invented Communities and Social Vulnerability: The Local Post-Disaster Dynamics of Extreme Environmental Events. Sustainability 2018, 10, 4457. [CrossRef]

(C) 2020 by the authors. Licensee MDPI, Basel, Switzerland. This article is an open access article distributed under the terms and conditions of the Creative Commons Attribution (CC BY) license (http://creativecommons.org/licenses/by/4.0/). 